\title{
Tata Kelola Sampah Rumah Tangga melalui Pemberdayaan Masyarakat dan Desa di Indonesia
}

\author{
Ani Marlina \\ Prodi Pendidikan Matematika, STKIP Kusuma Negara, Indonesia \\ rosadi.animarlina@gmail.com
}

\begin{abstract}
Abstrak
Penelitian ini dilatarbelakangi oleh fakta bahwa sampah rumah tangga telah menjadi permasalahan nasional yang belum ada solusinya secara komprehensif. Sampah plastik di Indonesia, yang mencemari lautan, volumenya terindikasi terbesar kedua di dunia. Tujuan penelitian ialah merumuskan cara meningkatkan keberdayaan masyarakat dalam mengelola sampah secara mandiri, dan merumuskan cara penguatan desa dalam tatakelola sampah di skala desa. Penelitian ini menggunakan metode kualitatif dengan pengumpulan data menggunakan pendekatan non interaksi (studi litelatur dan kebijakan) dan interaksi melalui wawancara mendalam terhadap stakeholder, seperti kepala desa, para pelaku pada Dinas Pemberdayaan Masyarakat dan Dinas Lingkungan Hidup. Hasil Penelitian sebagai berikut: (a) pemberdayaan dimulai dari pembangkitkan etik, moral, kesadaran, mindset, dan tanggung jawab terhadap lingkungan di masyarakat, (b) pemberdayaan masyarakat dalam tatakelola sampah rumah tangga efektif dilakukan mulai dari tingkat RT/RW, (c) penguatan desa diperlukan dengan cara delegasi kewajiban tatakelola sampah dari Kabupaten/Kota kepada desa, dan (d) perlu desain tatakelola sampah yang inovatif dan komprehensif sesuai dengan regulasi desa yang relevan. Kesimpulan Penelitian, 74.957 desa dapat didorong untuk dikonsolidasi menjadi gerakan nasional pengelolaan sampah rumah tangga yang efektif.
\end{abstract}

Kata kunci: desa, pemberdayaan, sampah rumah tangga, tata kelola.

\section{PENDAHULUAN}

Tantangan lingkungan era industri 4.0 tidak lebih mudah dibandingkan dengan generasi sebelumnya. Masalah sosial dan lingkungan masa depan juga akan jauh lebih kompleks terkait dengan tantangan ledakan jumlah penduduk, peningkatan kebutuhan permukiman, ketergantungan pasokan listrik dan jaringan internet yang sangat tinggi. Di sisi lain ketersediaan lahan untuk tempat tinggal semakin terbatas, hutan semakin berkurang bahkan mengalami kerusakan. Masalah lingkungan yang juga terus membesar ialah persoalan sampah rumah tangga, juga kecenderungan biaya rehabilitasi lingkungan yang semakin mahal. Perkotaan tumbuh semakin besar, semakin tinggi tingkat polusi, kepadatan, dan sebaliknya udara bersih, pemandangan indah dan permukiman asri menjadi semakin mahal. Kondisi demikian menjadi ironi pembangunan, di satu sisi semakin maju tetapi di sisi lain lingkungan semakin buruk.

\section{Latar Belakang}

Isu lingkungan masa depan semakin memperihatinkan, diantaranya, ialah sampah rumah tangga yang saat ini sudah menjadi masalah nasional dan bahkan dunia. Sampah bukan lagi ancaman potensial, tetapi sudah menjadi bencana aktual sejak 
lebih dari sepuluh tahun lalu. Peristiwa lingkungan dan kemanusiaan sangat menyedihkan terjadi ketika gunungan sampah di Tempat Pembuangan Akhir (TPA) Sampah Leuwigajah Cimahi longsor pada 21 Februari 2005. Pada saat itu, 157 jiwa melayang menjadi korban tertimbun sampah, dan dua kampung terhapus dari peta karena tergulung longsoran sampah.

Jutaan rumah tangga, baik di perkotaan maupun perdesaan, yang tersebar di seluruh Indonesia membuang sampah setiap hari. Perubahan gaya hidup mengkonsumsi makanan dalam kemasan dan perkembangan industri manufaktur turut mendorong peningkatan pertumbuhan volume sampah. Rumah tangga yang mengkonsumsi barang industri makanan dan minuman berubah menjadi "pabrik mini” sampah yang mengotori lingkungan. Volume sampah semakin besar seiring dengan pertumbuhan dan kepadatan penduduk yang semakin tinggi. Data Kementerian Lingkungan Hidup dan Kehutanan menunjukkan sampah rumah tangga telah menempati volume tertinggi dari seluruh jenis sampah di Indonesia. Secara nasional, volume sampah mencapai 200 ribu ton per hari atau setara dengan 73 juta ton per tahun. Dari sisi sumber, sampah rumah tangga paling dominan sebanyak $48 \%$, disusul pasar tradisional $24 \%$, dan kawasan komersial sebesar $9 \%$. Sisanya dari fasilitas publik, sekolah, kantor, jalan, dan sebagainya (KLH Media Briefing, 2014). Sumber terbaru menunjukkan bahwa pada tahun 2018 volume sampah di Indonesia mencapai 187,2 juta ton per tahun.

Skala persoalan sampah di Indonesia memang sudah sampai pada skala sangat kritis, satu di antaranya terlihat dari penampakan banyak sungai yang bermuara ke laut Jawa seolah menjadi TPA sampah sangat panjang dan menyedihkan. Sampah plastik dari Indonesia yang dibuang ke lautan telah menjadi nomor dua terbanyak di dunia setelah China. Sampah plastik tersebut telah menyebabkan kematian banyak hewan laut. Tanggal 11 bulan November 2018, seekor paus mati ditemukan oleh warga di Pulau Kapota di Desa Kapota Utara, Kecamatan Wangi-wangi Selatan, Kabupaten Wakatobi, Sulawesi Tenggara. Paus dari jenis sperm whale ditemukan dalam kondisi membusuk. Berdasarkan hasil peninjauan lapangan, jenis paus yang terdampar merupakan Paus Sperma (Physeter Macrocephalus) dengan ukuran panjang 9,5 meter dan lebar $437 \mathrm{~cm}$ dalam keadaan mati dan sudah mulai membusuk. Di dalam perut paus tersebut ditemukan gelas plastik 750 gr (115 buah), plastik keras 140 gr (19 buah), botol plastik 150 gr (4 buah), kantong plastik 260 gr (25 buah), serpihan kayu 740 gr (6 potong), sandal jepit 270 gr (2 buah), karung nilon $200 \mathrm{gr}$ (1 potong), tali rapia $3.260 \mathrm{gr}$ (lebih dari 1000 potong). Total berat basah sampah adalah $5,9 \mathrm{~kg}$.

Bukan tidak mungkin pada suatu saat berbagai pulau padat penduduk di Indonesia, pantainya sudah lebih banyak sampah daripada ikan. Jika hal ini terjadi, generasi masa depan akan sangat buruk kehidupannya. Tanda-tanda tersebut saat ini sangat jelas terjadi, sehingga jika tidak ada upaya yang efektif dari pemerintah dan masyarakat, mungkin seluruh pantai indah di Indonesia akhirnya akan tertutup sampah, terumbu karang rusak, ikan-ikan mati, pariwisata mati, dan ekonomi lumpuh. Perlu disadari oleh semua pihak, bahwa jika sampah terus dalam kondisi seperti sekarang pertumbuhannya, pada titik tertentu masalah sampah menjadi ledakan masalah yang tidak terkendali. Dampak ledakan persoalan sampah akan jauh lebih besar dan lebih sistemik, bahkan dibandingkan dengan bom waktu eksplosif. Ledakan sampah juga terbukti dapat menimbulkan korban jiwa, menjadi teror, dan nestapa kehidupan berkepanjangan. 


\section{Keadaan Terkini}

Pada banyak rumah tangga, terutama yang tinggal di permukiman padat penduduk, pengelolaan sampah secara mandiri relatif jarang ditemui. Hampir seluruh rumah tangga membuang sampah tanpa dipilah terlebih dahulu. Sampah organik dan anorganik disatukan dalam plastik dan dibuang. Mereka membuang sampah ke Tempat Penampungan Sementara (TPS). Di perdesaan, bahkan banyak rumah tangga yang membuang sampah ke sungai, ke kebun, ke jalan, bahkan ke belakang rumah sendiri. Hanya sebagian kecil rumah tangga yang telah mengelola sampah secara mandiri. Sampah organik dibuat pupuk, dan sampah non organik dibakar, atau diambil para pemulung.

Pemerintah daerah, yang ditugaskan mengelola sampah, secara umum belum efektif menyelesaikan masalah sampah rumah tangga. Anggaran, sumber daya manusia (SDM), fasilitas pengelolaan sampah oleh Satuan Kerja Perangkat Daerah (SKPD) belum sebanding dengan besarnya volume sampah, sehingga hanya sebagian saja sampah yang berhasil dikelola sampai ke Tempat Pembuangan Akhir (TPA). Tanpa partisipasi masyarakat yang memadai, masih banyak sampah yang dibuang sembarangan, sekalipun sudah disediakan berbagai TPS, TPA, serta sarana prasarana pendukungnya. Kondisi demikian terjadi pada mayoritas kabupaten/kota di Indonesia. Mereka gagal melayani seluruh sampah rumah tangga agar tidak mencemari lingkungan sekitar. Sampah yang tidak terkelola oleh pemerintah daerah terbawa aliran sungai dan tersebar secara tidak terkendali. Sudah menjadi pemandangan biasa, sampah teronggok di pusat pusat keramaian dan di jalan protokol. Pemerintah daerah sampai saat ini umumnya hanya mengandalkan APBD, mereka belum mempunyai strategi yang efektif untuk mengelola seluruh sampah rumah tangga. Pemerintah daerahpun sering gagal menggerakkan partisipasi masyarakat untuk mengelola sampah secara mandiri, sehingga masyarakat menjadi bagian dari masalah penghasil sampah bukan bagian dari solusi penangananya.

Mencermati kegagalan pemerintah daerah, perlu terobosan untuk mengatasi sampah yang satu diantaranya ialah upaya menggeser/mendelegasi sebagian kewajiban pengelolaan sampah dari pemerintah daerah ke pemerintah desa. Kapasitas kelembagaan desa untuk mengelola sampah di desanya masing-masing belum dioptimalkan. Penguatan kelembagaan desa sangat mendesak dilakukan, agar desa bisa memanfaatkan sumber daya yang dimilikinya secara optimal untuk tatakelola sampah. Pemerintahan desa saat ini, mempunyai anggaran cukup besar dan disertai wewenang untuk mengalokasikan program pengelolaan sampah dalam Anggaran Pendapatan dan Belanja Desa (APBDes). Pemerintahan Desa juga mempunyai potensi besar untuk menggerakkan partisipasi langsung masyarakat. Delegasi kewenangan dan kewajiban tatakelola sampah oleh pemerintahan desa perlu dirinci dalam sebuah penelitian yang komprehensif. Secara teoritis sangat memungkinkan untuk ditindaklanjuti, karena luas wilayah desa relatif terjangkau, volume sampah terbatas, dan sumber daya manusia desa memungkinkan untuk diberdayakan.

Untuk mengatasi masalah sampah di Indonesia, diperlukan riset pemberdayaan masyarakat dan desa (Isbandi, 2012). Hasil riset ini diperlukan pemerintah kabupaten/kota, desa, dan masyarakat, sehingga dapat diterapkan di berbagai desa yang saat ini masih belum berhasil mengelola sampahnya secara mandiri, belum bisa mewujudkan kehidupan lingkungan yang bersih, bebas residu sampah, dan 
memanfaatkan sampah sebagai satu dari berbagai sumber daya ekonomi, baik dari sampah organik yang menjadi kompos, maupun pemanfaatan sampah anorganik untuk diolah dan didaur ulang. Sehingganya dari masalah yang diteliti dibatasi pada aspek krusial saja yaitu: (a) bagaimana pola dan tahapan pemberdayaan masyarakat agar berpartisipasi efektif dalam tatakelola sampah rumah tangga di Indonesia dan (b) bagaimana model perberdayaan desa agar mempunyai kapasitas dalam tata kelola sampah rumah tangga di Indonesia. Tujuan penelitian ini ialah sebagai berikut: (a) merumuskan pola dan tahapan pemberdayaan masyarakat yang efektif dalam tatakelola sampah rumah tangga, dan (b) merumuskan model perberdayaan desa agar mempunyai kapasitas dalam tata kelola sampah rumah tangga di Indonesia.

Menurut Badan Pusat Statistik (2010), jumlah penduduk Indonesia kurang lebih mencapai 247,7 juta jiwa. BPS memperkirakan terus mengalami pertumbuhan yang signifikan, bahkan akan tumbuh menjadi 271.066.400 jiwa pada tahun 2020 . Pertumbuhan penduduk ini sungguh merupakan tantangan lingkungan yang besar, karena membutuhkan daya dukung lingkungan yang harus semakin baik. Di sisi lain pertumbuhan penduduk telah meningkatkan jumlah sampah yang sehingga menimbulkan persoalan lingkungan, kesehatan, dan sosial yang terus membesar.

Meningkatnya jumlah penduduk, dan keterbatasan lahan untuk menampung sisa konsumsi, menjadi satu di antara berbagai faktor penyebab volume sampah yang terus menggunung. Sampah yang menumpuk itu sudah tentu akan mengganggu kenyamanan dan dan kesehatan penduduk di sekitarnya, karena menimbulkan bau yang tidak sedap, mengundang lalat, dan dapat mendatangkan wabah penyakit. Sampah sangat merugikan jika tidak dikelola sejak awal dengan cara yang benar. Sebaliknya, jika dikelola dengan baik dapat diubah menjadi barang yang bermanfaat. Sayangnya, komitmen dan tanggung jawab serta berbagai upaya mendorong pemanfaatan sampah belum dilaksanakan secara besar-besaran,

Pembangunan industri yang tinggi dan perubahan gaya hidup masyarakat menjadi lebih instan telah memberi tekanan kepada masalah lingkungan. Lingkungan sering kali dikorbankan untuk memenuhi kebutuhan dasar penduduk dengan cepat. Tantangannya adalah mengelola tingginya pertumbuhan penduduk tanpa mengeksploitasi sumber daya alam secara irasional (Putrawan, 2014).

Sampah erat kaitannya dengan kesehatan masyarakat, karena dari sampah tersebut hidup berbagai mikroorganisme penyebab penyakit (bakteri pathogen), dan juga binatang serangga sebagai pemindah/penyebar penyakit (vector). Oleh sebab itu, sampah harus dikelola dengan baik sampai sekecil mungkin agar tidak mengganggu atau mengancam kesehatan masyarakat. Pengelolaan sampah yang baik, bukan saja untuk kepentingan kesehatan, melainkan juga untuk keindahan lingkungan. Banyak pihak masih mengabaikan pengelolaan sampah, padahal tersedia teknologi yang mudah, ramah, dan murah, Satu di antaranya ialah dengan pembuatan mikro organisme lokal (mol). Mayoritas sampah organik yang menimbulkan masalah bisa dikelola menjadi mol, seperti mol berbahan nasi, sayur, buah-buahan, tulang, dedaunan, akar-akaran, dan mol campuran sampah organik lainnya. Dengan begitu, sampah bisa termanfaatkan lagi, jika pengelolaan sampah, khususnya sampah organik yang menyebabkan bau langsung diproduksi sebagai sumber bahan mol.

Pengelolaan sampah di suatu daerah akan membawa pengaruh, baik bagi masyarakat maupun lingkungan di daerah itu sendiri. Hal ini dikuatkan oleh 
pendapat (Veitch \& Arkkelin, 1995) yang mengatakan, bahwa manusia selalu berproses dan berpikir tentang lingkungannya, dan mempunyai sifat pengetahuan yang berbeda-beda tentang alam sekitar. Pengelolaan sampah yang baik akan memberikan pengaruh yang positif terhadap masyarakat dan lingkungannya, seperti berikut: (a) Sampah dapat dimanfaatkan untuk menimbun lahan semacam rawarawa dan dataran rendah, (b) Sampah dapat dimanfaatkan untuk pupuk, (c) Sampah dapat diberikan untuk makanan ternak setelah menjalani proses pengelolaan yang telah ditentukan lebih dahulu untuk mencegah pengaruh buruk sampah tersebut pada makanan ternak, (d) Pengelolaan sampah dapat menyebabkan berkurangnya tempat untuk berkembang biak serangga atau binatang pengerat, (e) Menurut insidensi kasus penyakit menular yang erat hubungannya dengan sampah, (f) Keadaan estetika lingkungan yang bersih menimbulkan kegairahan hidup masyarakat, dan (g) Keadaan lingkungan yang baik mencerminkan kemajuan budaya masyarakat, menghemat pengeluaran dana kesehatan suatu negara sehingga dana itu dapat digunakan untuk keperluan lain.

Pengelolaan sampah yang kurang baik dapat memberikan pengaruh negatif bagi kesehatan lingkungan, kehidupan sosial ekonomi, dan budaya masyarakat. Undangundang Republik Indonesia (2009) mengharuskan mengelola dan melindungi lingkungan dengan bijak. Pengelolaan yang meliputi pengurangan (reduce), penggunaan kembali (reuse), dan pengsiklusan kembali (recycle) di lingkungan harus dilakukan demi terciptanya kebersihan dan kenyamanan (Permen Lingkungan Hidup, 2012). Pemerintah telah mengeluarkan regulasi berupa Undang-Undang Republik Indonesia (2008) tentang pengelolaan sampah dan berbagai produk hukum turunannya. Semua ini ialah untuk mengatasi sampah secara tuntas. Sekalipun demikian, berbagai masalah utama sampah di Indonesia belum banyak mengalami perbaikan. Pemilahan, pengurangan, dan pengelolaan sampah belum menjadi kultur di negara ini. Pada sisi lain, teknologi sederhana, seperti mol (untuk pembuatan kompos organik dari sampah) dalam rumah tangga belum optimal. Kondisi ini mencerminkan perlunya kerja keras semua pihak untuk bisa membuat instrumen tatakelola sampah secara lebih baik, sebagaimana diamanatkan dalam PPRI (2012).

Undang-Undang Republik Indonesia (2008) tentang Pengelolaan Sampah menjadi payung hukum pengelolaan sampah secara terpadu dan komprehensif. Di dalamnya diatur mengenai berbagai hal yang memberikan kepastian hukum bagi masyarakat untuk memperoleh layanan pengelolaan sampah yang baik. UndangUndang ini juga sudah mengatur hak, tugas, wewenang, dan tanggung jawab pemerintah, pemerintah daerah, dan masyarakat. Secara prinsip, Undang-Undang pengelolaan sampah mengatur bahwa pencemaran lingkungan akibat sampah menjadi tanggungjawab pemerintah, dan penanganan pencemaran limbah merupakan tanggungjawab pelaku usaha. Demikian pula dengan Undang-Undang Republik Indonesia (1992) tentang Perumahan dan Permukiman, didalamnya ditekankan bahwa pembangunan lingkungan permukiman selalu menyediakan prasarana lingkungan. Prasarana lingkungan dimaksud, antara lain, ialah jaringan saluran pembuangan air limbah dan tempat pembuangan sampah.

Esensi pengelolaan sampah juga tersurat secara tegas dalam Undang-Undang Republik Indonesia (2004) tentang Pemerintahan Daerah. Disebutkan bahwa pengaturan tugas dan wewenang antara Pemerintah, Pemerintah Provinsi, dan Pemerintah Kabupaten/Kota dalam pengelolaan sampah, sesuai dengan wewenang 
otonomi daerah. Pada Pasal 14 Ayat (1) Undang-Undang tersebut dinyatakan bahwa satu di antara berbagai urusan wajib yang menjadi kewenangan pemerintahan daerah ialah berbagai urusan berskala kabupaten/kota, antara lain, pengendalian lingkungan hidup. Pengendalian lingkungan hidup ini, diantaranya, termasuk pengelolaan sampah, yang meliputi pengumpulan, pengangkutan, penampungan, pemusnahan atau pengolahan, dan penyediaan TPA.

Definisi sampah rumah tangga selalu diacu kepada Peraturan Pemerintah Republik Indonesia (2012) tentang Pengelolaan Sampah Rumah Tangga dan Sampah Sejenis Sampah Rumah Tangga. Dalam peraturan pemerintah ini disebutkan bahwa "Sampah rumah tangga ialah sampah yang berasal dari kegiatan sehari-hari dalam rumah tangga yang tidak termasuk tinja dan sampah spesifik." Sampah spesifik ialah sampah sejenis sampah rumah tangga yang berasal dari kawasan komersial, kawasan industri, kawasan khusus, fasilitas sosial, fasilitas umum, dan/atau fasilitas lainnya.

Sampah dapat bersumber dari: (a) Pemukiman: sampah ini terdiri dari bahanbahan padat sebagai hasil kegiatan rumah tangga yang sudah dipakai dan dibuang, (b) Tempat umum: sampah ini berasal dari tempat umum, seperti pasar, tempattempat hiburan, terminal bus, stasiun kereta api, dan sebagainya, (c) Perkantoran: sampah dari perkantoran pendidikan, perdagangan, departemen, perusahaan dan sebagainya, (d) Jalan Raya, sampah ini berasal dari pembersihan jalan, yang umumnya terdiri dari: kertas-kertas, kardus-kardus, debu, batu-batuan, pasir, sobekan ban, onderdil-onderdil kendaraan yang jatuh, daun-daun, plastik dan sebagainya, dan (e) Industri, sampah ini berasal dari kawasan industri (industrial waste), termasuk sampah yang berasal dari pembangunan industri, dan segala sampah yang berasal dari proses produksi.

Secara operasional tatakelola sampah rumah tangga diatur dalam oleh setiap pemerintah daerah melalui pembuatan peraturan daerah. Dasar hukum pembuatan perda ini sangat banyak, antara lain Peraturan Pemerintah Republik Indonesia. (PPRI, 2012), Peraturan Menteri Dalam Negeri (Permendagri, 2010), dan Peraturan Menteri Negara Lingkungan Hidup (2011). Selain Peraturan Menteri Dalam Negeri dan Peraturan Menteri Lingkungan Hidup yang memberi acuan pengelolaan sampah dan pembuatan perdanya, Pemerintah Pusat melalui Direktorat Pengembangan Penyehatan Lingkungan Permukiman Direktorat Jenderal Cipta Karya Kementerian Pekerjaan Umum dan Perumahan Rakyat pada Tahun 2017 menerbitkan Panduan Penyusunan Rancangan Peraturan Daerah Tentang Pengelolaan Sampah. Di dalamnya dimuat segala hal yang dibutuhkan dalam porses pembuatan perda, bahkan sudah dilengkapi dengan contoh naskah akademiknya. Jadi tiga kementerian sekaligus memberikan arahan detail tentang tatakelola sampah, yaitu Kementrian Dalam Negeri, Kementerian Lingkungan Hidup, dan Kementerian Pekerjaan Umum.

Beberapa kabupaten sudah membuat perda sendiri, sebagaimana dapat ditelusur dalam dokumen Sistem Jaringan Dokumentasi dan Informasi Hukum (SDJIH) Kementrian Dalam Negeri. Satu di antara berbagai Kabupaten yang telah mempunyai perda ialah kabupaten Garut, yaitu Peraturan Daerah Kabupaten Garut (Perda, 2014) tentang Pengelolaan Sampah Rumah Tangga Dan Sampah Sejenis Sampah Rumah Tangga. Isi Perda ini telah disesuaikan kepada panduan yang menjadi regulasi operasional. Dalam perda tersebut sudah diatur mengenai proses 
pengeloaan sampah mulai dari rumah tangga sampai ke TPA, juga berbagai tugas pengelolaannya.

Perda tersebut memuat, antara lain, tugas dan kewenangan pemda untuk menyelenggarakan pengelolaan sampah skala kabupaten sesuai dengan norma, standar, prosedur, dan kriteria yang ditetapkan oleh Pemerintah. Selain itu, juga tercakup regulasi mengenai tatacara pengelolaan sampah mulai dari pengumpulan, pemilahan sampai dengan pemrosesan akhir, sarana prasarana, serta hak dan kewajiban berbagai pihak terkait, termasuk kewajiban pengelola Kawasan dan produsen produk yang menimbulkan sampah. Pengelola Kawasan, bahkan mempunyai kewajiban yang detail, antara lain, Pengelola kawasan permukiman, kawasan komersial, kawasan industri, kawasan khusus, fasilitas umum, fasilitas sosial, dan fasilitas lainnya wajib menyediakan: (a) fasilitas pemilahan sampah; (b) lokasi dan fasilitas TPS, TPS 3R dan/atau alat pengumpul sampah terpilah, (c) meminimalkan jumlah sampah yang dihasilkan, dan (d) bertanggung jawab atas sampah yang ditimbulkan oleh aktivitas kegiatannya.

Pola pemantauan, secara konsepsional, juga sangat komprehensif, karena memperhatikan secara cermat perbandingan antara tingkat pencapaian kinerja pengelolaan sampah secara periodik dan target atau sasaran yang harus dipenuhi. Perbandingan ini meliputi berbagai aspek berikut: (a) standar pelayanan minimal, (b) standar operasional prosedur, (c) norma, standar, pedoman dan criteria, dan (d) pengelolaan dan pemantauan lingkungan. Selain itu, ada kewajiban untuk menyajikan data dan informasi pengelolaan sampah rumah tangga dan sampah sejenis sampah rumah tangga. Data dan informasi pengelolaan sampah sebagaimana dimaksud, antara lain, memuat: (a) sumber sampah, (b) timbunan sampah, (c) komposisi sampah, (d) karakteristik sampah, (e) fasilitas pengelolaan sampah rumah tangga dan sampah sejenis sampah rumah tangga, dan (f) data dan informasi lain terkait pengelolaan sampah rumah tangga dan sampah sejenis sampah rumah tangga yang diperlukan dalam rangka pengelolaan sampah.

Beberapa desa di Indonesia melakukan terobosan pengelolaan sampah dengan membuat perdes tentang pengelolaan sampah rumah tangga. Akan tetapi, perdes ini belum merinci teknik tatakelola sampah mulai dari persiapan, perencanan, pelaksanaan, sampai dengan pemantauan dan pengevaluasian. Di antara desa tersebut ialah Desa Segobang Kecamatan Licin Kabupaten Banyuwangi yang menerbitkan Peraturan Desa Segobang (2017) tentang Pengelolaan Sampah. Dalam regulasi tingkat desa ini diatur mengenai Lembaga Pengelola desa yang dilaksanakan oleh Unit Pengelola Sampah sebagai Unit Usaha dari BUMDesa. Dalam pelaksanaanya, Unit Pengelola Sampah dapat memfasilitasi pembentukan lembaga pengelola sampah pada tingkat RT sesuai dengan kebutuhan. Bentuk Lembaga Pengelola Sampah tingkat RT sebagaimana yang dimaksud adalah Bank Sampah (Peraturan Desa Segobang, 2017).

Optimisme pemberdayaan masyarakat dalam pengelolaan sampah diperlihatkn oleh hasil penelitian mengenai implementasi pengelolaan sampah pada salah satu pilot project di kabupaten Garut. Tiga temuan penting ialah sebagai berikut: (a) pilot project pengelolaan sampah rumah tangga berbasis masyarakat di tarogong, kabupaten garut berjalan secara baik dengan prinsip 3r (reduce, reuse, recycle) dan berhasil mengurangi volume sampah yang dibuang ke tps hingga 70\%; (b) model pengelolaan sampah rumah tangga berbasis masyarakat dengan prinsip $3 \mathrm{r}$ merupakan solusi paradigmatis; dan (c) problematika utama dalam pelaksanaan 
model ini ialah bagaimana mengubah paradigma "membuang sampah" menjadi "memanfaatkan sampah". problematika lain yang teridentifikasi ialah: (a) pemerintah daerah belum memberikan apresiasi terhadap masyarakat yang telah melakukan pemilahan sampah, (b) tidak ada mekanisme dan person yang memantau dan mengevaluasi kegiatan; (c) penerapan kebijakan pengelolaan sampah berbasis masyarakat dengan prinsip $3 r$ tidak diikuti penyediaan sarana dan prasarana penunjang, (d) pemilahan sampah di rumah tangga kurang tuntas, dan (e) tidak ada kaderisasi untuk mencari pengurus baru yang memiliki kapabilitas dan integritas.

Hal yang diperlukan untuk meningkatkan peran serta masyarakat ialah sebagai berikut: (a) pemerintah, pengurus rt/rw, dan pengelola mendidik masyarakat secara terencana dan terukur tentang pengelolaan sampah yang benar, (b) pemerintah mengatur dan memberikan insentif dan disinsentif untuk memotivasi masyarakat, (c) pemerintah, pengurus $\mathrm{rt} / \mathrm{rw}$, dan pengelola membuat mekanisme dan menentukan orang untuk memantau dan mengevaluasi pengelolaan sampah berbasis masyarakat, (d) pemerintah menyediakan sarana dan prasarana pengelolaan sampah dengan model ini, (e) pengelola dan pengurus rt/rw mencari strategi kaderisasi pengelola, dan (f) model pengelolaan sampah rumah tangga berbasis masyarakat layak dikembangkan jadi model pengelolaan sampah rumah tangga di perkotaan.

Berbagai hasil riset sebelumnya menunjukkan bahwa tidak semua sampah permukiman berhasil dikelola pemerintah. Keterbatasan armada, dan area pelayanan membuat banyak area tidak terlayani dengan baik. Sebagian sampah permukiman tersebut dibuang sembarangan, terbawa oleh aliran sungai dan tersebar tidak terkendali. Sampah permukiman menutup saluran air, mengotori kota, mencemari kolam dan sawah. Walau peraturan sudah ada, namun lagi-lagi sosialisasi kurang optimal dan tekhnik pengelolaan yang tidak murah (Permendagri, 2010).

Masalah utama pemerintah dalam pengelolaan sampah ialah kapasitas pengangkutan (carrying capacity) mempunyai keterbatasan dalam menampung sampah dan memberdayakan masyarakat. Seperti diungkapkan oleh Barrow (2006), langkah pengambilan keputusan dalam manajemen lingkungan harus dimulai dari observasi hingga ditemukan nilai formulasi. Selanjutnya diidentifikasi tujuannya dengan pertimbangan resiko yang harus disiapkan segala sesuatunya. Langkah berikutnya ialah menemukan formulasi alternatif sebagai solusi untuk dievaluasi dengan keputusan dilanjutkan atau dihentikan, sehingganya akan menemukan satu formulasi untuk diimplementasikan dengan terus memonitor perkembangan dan terus dilakukan evaluasi untuk menilai keefektifan dari kebijakan yang telah disepakati.

Publikasi global environmental change, yang memiliki irisan relevan dengan riset ini, menyatakan bahwa "... relationship between environmental management, ecosystem goods and services, human well being, and their relationship to environmental governance, which uncovers the mechanics of how valuation can inform decision-making via different institutional arrangements" (Phelps, Dermawan \& Garmendia, 2017). Kebijakan yang dibutuhkan harus dari institusi yang berbeda tetapi dengan tujuan sama, yaitu untuk mengendalikan lingkungan. Pemerintah harus terus memantau dan membuat kebijakan terkait lingkungan pada berbagai aspek kehidupan, karena hanya pemerintah yang mempunyai kewenangan untuk mengendalikan kondisi lingkungan hidup. 


\section{Kerangka Teori}

Terdapat masalah substantif yang tersembunyi dibalik tumpukan sampah yang tidak terkelola. Masalah sampah bukan saja soal pencemaran lingkungan, melainkan juga masalah warga yang melanggar aturan kebersihan. Lebih jauh, domain persoalan lingkungan bukan saja masalah kesadaran tetapi juga masalah etik dan moral lingkungan, bukan saja masalah perencanaan dan anggaran tetapi juga masalah militansi dan komitmen setiap Pemangku kepentingan (stakeholders).

Di balik tumpukan sampah, terlihat adanya pelanggaran kaidah pengelolaan hidup bersih. Selain itu, juga mencerminkan kondisi masyarakat yang cenderung abai pada nilai tanggung jawab sosial, nilai proaktif, nilai menjadi manusia yang berguna, dan visi kehidupan yang ideal. Jadi dapat diindikasikan, secara substantif, paling kurang ada lima masalah dibalik tumpukan sampah.

Masalah pertama ialah keterbatasan pemerintah. Secara umum pemerintah belum berhasil dalam mengelola sampah, kewajiban permerintah daerah untuk mengelola sampah dalam skala kabupaten terbukti gagal, karena banyak hal, antara lain, ialah keterbatasan angaran, kapasitas kelembagaan, dibandingkan dengan besarnya volume sampah yang terus menggunung.

Masalah kedua ialah etika lingkungan. Manusia ialah mahluk yang mempunyai nilai etika dan estetika. Etika menempatkan manusia mempunyai kepekaan rasa untuk berperilaku dengan baik, sedangkan estetika memberi rasa keindahan kepada manusia. Estetika membuat manusia menikmati keindahan dan mendesain diri dan lingkungannya untuk membuat keindahan. Sayangnya, kita sedang bermasalah dalam hal etika lingkungan. Sekalipun tidak sedetikpun kita bisa melepaskan dari kebutuhan lingkungan, tapi kurang beretika terhadap lingkungan dimana kita hidup, makan, bernafas dan berkembang biak. Padahal etika ialah satu di antara berbagai ciri kemanusiaan yang sangat agung. Etika atau filsafat moral ialah cabang filsafat yang mengandung serangkaian sistem untuk mempertahankan, dan merekomendasikan konsep-konsep perilaku yang benar dan salah. Etika memberi jawaban terhadap pertanyaan tentang moralitas manusia. Etika menjaga agar manusia dapat mengimplementasikan konsep kehidupan yang baik dan menghindari kejahatan. Etika mengajarkan manusia melakukan hal yang benar dan menghindari yang salah, memuja kebajikan dan menghindari keburukan. Keadaran etika akan mendorong untuk berperilaku adil terhadap sesama dalam pengelolaan lingkungan dan menghindari kejahatan lingkungan.

Pembahasan etika dalam pengelolaan lingkungan sudah semakin mendesak. Etika lingkungan sudah selayaknya dipelajari sebagaimana banyak etika lain yang sudah eksis dalam berbagai ranah kehidupan. Salah satu mata kuliah dalam pendidikan magister manajemen misalnya ialah mengenai etika bisnis, agar tatakelola bisnis beretika. Demikian pula dalam kehidupan para wartawan mempunyai kode etik jurnalistik. Selain bisnis dan jurnalis, dikenal pula kode etik kedokteran, kode etik guru dan dosen. Perhatian warga dunia terhadap etika sudah sedemikian rupa, sehingga di banyak negara dunia sudah berperilaku etik bahkan terhadap binatang Mereka membangun sebuah konsep animal walfare, yang diterapkan pada setiap binatang. Mereka menerapkan standar perlakuan yang baik pada binatang (hewan ternak) ketika dipindah ke kandang, diberi makan, dipotong berdasarkan standar yang ketat sesuai dengan kaidah animal walfare. Australia misalnya, menerapkan kebijakan animal walfare, hanya mengekspor sapi pada 
importir yang memenuhi standar kandang, standar pakan, standar pengiriman yang tidak menyakitkan dan menyengsarakan binatang. Mereka sudah memiliki standar etika lingkungan yang sangat tinggi. Binatangpun dilindungi, apalagi manusia dan kehidupan secara umum.

Masalah ketiga ialah moral lingkungan. Moral lingkungan dikonsepkan sebagai sebuah nilai universal kebenaran yang harus dipegang teguh oleh warga dan pemerintah dalam memperlakukan lingkungan. Lingkungan sebagai subyek yang mempunyai eksistensi harus diperlakukan secara bermoral. Sebagai subyek, lingungan mempunyai perilaku yang reaktif terhadap tindakan manusia. Jika diperlakukan dengan buruk, lingkungan secara otomatis memberikan balasan yang jauh lebih buruk, lingkungan memberikan feedback sepadan dengan tindakan moral kita pada lingkungan. Bangsa besar ialah bangsa yang bisa menghargai lingkungannya. Moral lingkungan perlu menjadi konsep baru, agar kita dapat menanamkan prinsip moral lingkungan sebagai bagian penting dari moral kehidupan. Para ahli pendidikan lingkungan seharusnya membuat upaya agar isi moral lingkungan dapat mewarnai pelajaran, seperti biologi, ilmu pengetahuan alam, ilmu pengetahuan sosial, ilmu alamiah dasar, dan pelajaran geografi. Materia moral lingkungan bisa dibuat sebagai satu muatan lokal. Proses pendidikan moral lingkungan melalui pengayaan muatan lokal ini sangat dibutuhkan, terutama untuk sekolah-sekolah yang terletak di daerah rawan pencemaran, sampah, dan kerusakan lingkungan lainnya. Contohnya, warga yang tinggal di daerah sekitar sungai Citarum, warga sekitar kawasan industri, warga sekitar hutan yang habis dibabat oleh pembalakan liar, perlu mendapat materi moral lingkungan secara lebih besar dan lebih relevan dengan masalah dan tantangan lingkungan di sekitarnya.

Masalah keempat ialah kesadaran lingkungan. Masalah kesadaran lingkungan sesungguhnya telah mendapat perhatian paling banyak dibandingkan dengan etika lingkungan dan moral lingkungan. Kesadaran lebih mudah dideteksi dan dideskripsikan dibandingkan dengan ektika dan moral lingkungan. Banyak pihak, mulai dari pemerintah, tokoh agama, hingga tokoh masyarakat mengambil simpulan, bahwa persoalan lingkungan itu terjadi, karena kesadaran lingkungan yang rendah, sehingga diperlukan level kesadaran lebih tinggi. Kesadaran lingkungan ialah manifestasi dari kesadaran mendalam akan eksistensi diri sendiri. Manusia ialah mahluk sangat sempurna, yang membutuhkan ruang hidup ideal untuk tumbuh dan berkembang secara sempurna, baik secara pribadi, keluarga maupun secara sosial dalam harmoni dengan alam sekitar.

Masalah kesadaran perlu diperdalam terhadap berbagai hal, antara lain, ialah: (a) sadar akan tugas kehidupan, bahwa mengelola alam dengan baik adalah tugas kehidupan yang melekat padanya sebagai mahluk Tuhan dan sebagai bagian dari alam. (b) Sadar akan ketergantungan pada alam, bahwa kita sangat membutuhkan alam yang lestari, untuk bisa hidup sehat sangat membutuhkan air, udara, tanah dan air. Teknologi sama sekali tidak dapat menggantikan kebutuhan terhadap alam, bahkan juga tidak dapat menggantikan kebahagiaan alamiah. (c) Sadar akan hukum alam, alam selalu membalas pelakuan secara setimpal. Alam menjawab pencemaran dengan penyakit dan penderitaan. Sebaliknya alam berterima kasih pada setiap tanaman yang dirawat dengan oksigen yang bersih, pembuatn kompos dengan hasil tanaman yang subur. Hukum alam mengajarkan bahwa mencintai alam akan kembali mendapatkan cinta dan merusak alam akan mendatangkan bencana. (d) Sadar akan hukum negara, merusak alam, membuang sampah 
sembarangan, membuang B3 dan bahkan abai pada lingkungan adalah melanggar hukum dan sampa tercelanya dengan pelanggaran hukum kriminal yang mengandung unsur pidana.

Masalah kelima ialah kebudayaan. Budaya merupakan seperangkat adat, tradisi, dan nilai-nilai masyarakat atau komunitas, seperti kelompok etnis atau bangsa. Dalam konteks budaya lingkungan, nilai-nilai dan budaya yang perlu dikembangkan adalah sebagai berikut: (a) budaya malu membuang sampah sembarangan, (b) budaya kerja sampai tuntas sampai dengan sampah, (c) budaya bersih, (d) budaya gotong royong mengelola lingkungan. Perlu upaya lebih keras dalam mengembangkan budaya peduli lingkungan. Pendidikan ialah satu di antara berbagai proses mengembangkan budaya melalui upaya peningkatan pengetahuan yang diperoleh dari waktu ke waktu. Mengembangkan jati diri masyarakat yang berbudaya tinggi dan eksis dalam percaturan bangsa lain. Walaupun secara universal terdapat aliran multikultur yang menghargai eksistensi dan saling menghormati antar budaya yang berbeda, namun dalam konteks tatakelola sampah dapat dipastikan bahwa semua jenis budaya yang baik mengharuskan tata kelola lingkungan yang baik pula. Kemampuan mengelola lingkungan menjadi salah satu indikator sejauh mana sebuah bangsa, sebuah komunitas, dan sebuah kelompok masyarakat memiliki kebudayaan tinggi.

Dalam kontek pengelolaan sampah rumah tangga, pemberdayaan masyarakat memerlukan pelibatan dan penguatan institusi desa (Isbandi, 2012). Pelibatan desa sangat strategis dan efektif, karena desa mempunyai interaksi lebih intensif dengan warganya masing-masing. Rentang kendali pemerintah desa terhadap RT/RW dan manajemen sampah didesanya jauh lebih baik dibandingkan dengan pemerintah kabupaten/kota. Pemerintahan desa dapat memonitor pekembangan desanya secara langsung setiap hari, dan bisa setiap pagi dan sore. Dengan demikian, bukan hanya masyarakat yang perlu diberdayakan dalam pengelolaan sampah tetapi juga desa, desa dalam pengertaian institusi yang mengelola kesatuan wilayah tertentu. Delegasi tugas pengelolaan sampah kepada pemerintatah desa, merupakan pendekatan baru karena Perda tata kelola sampah di seluruh Kabupaten/Kota di Indonesia yang ada sekarang ini ialah perda yang mengatur kewajiban pemerintah daerah dalam mengelola sampah pada skala kabupaten/Kota. Jadi domain perda selama ini ialah pemerintah kabupaten/kota, yang dalam pelaksanaannya dilaksanakan oleh SKPD, PD kebersihan, atau Lembaga yang ditunjuk. Regulasi yang sudah ada hanya mampu menyelesaikan persoalan sampah rumah tangga secara marginal, dalam arti, hanya sebagian tempat, sebagian sampah, dan sebagian kewajiban. Implementasi perda belum dapat menyelesaikan soal sampah secara komprehensif. Sebagian sampah tetap saja dibuang ke sungai, sebagaimana ditunjukkan oleh sungai Citarum, sungai Cimanuk, dan berbagai sungai besar lain di pulau Jawa.

Dibutuhkan keterlibatan desa secara lebih luas. Potensi 74.957 desa di Indonesia perlu diaktivisasi agar terlibat menggerakan jutaan rumah tangga mengelola sampahnya sendiri. Momentum ini harus dirumuskan dengan pendekatan yang benar dan dengan riset yang komprehensif. Peran dan fungsi desa dalam pengelolaan sampah permukian perlu diperkuat. Saat ini, ada 74.957 desa di Indonesia yang bisa digerakan untuk mengelola sampah. Secara prinsip tata kelola kebijakan publik dan karakteristik masyarakat di desa seluruh Indonesia sangat mirip satu sama lainnya. Desa mempunyai instrumen yang lengkap berupa Rencana Pembangunan Jangka Menengah Desa (RPJMDes), Rencana Kerja 
Pemerintah Desa (RKPDes), dan Anggaran Pendapatan dan Belanja Desa (APBDes) yang berpihak pada lingkungan, terutama tata kelola sampah.

Undang-Undang No 6 Tahun 2014 tentang Desa, menyebutkan bahwa pemberdayaan masyarakat desa ialah upaya mengembangkan kemandirian dan kesejahteraan masyarakat dengan meningkatkan pengetahuan, sikap, keterampilan, perilaku, kemampuan, kesadaran, serta memanfaatkan sumber daya melalui penetapan kebijakan, program, kegiatan, dan pendampingan yang sesuai dengan esensi masalah dan prioritas kebutuhan masyarakat Desa. (Pasal 1 angka 12).

Kegiatan pemberdayaan masyarakat desa yang diprioritaskan, antara lain, ialah: (a) Peningkatan partisipasi masyarakat dalam proses perencanaan, pelaksanaan dan pengawasan pembangunan Desa, (b) Pengembangan kapasitas masyarakat Desa yang dilaksanakan di Desa setempat, (c) Pengembangan ketahanan masyarakat Desa, (d) Pengembangan ketahanan keluarga, (e) Pengelolaan dan pengembangan sistem informasi Desa melalui pengembangan kapasitas dan pengadaan aplikasi perangkat lunak (software) dan perangkat keras (hardware) komputer untuk pendataan dan penyebaran informasi pembangunan dan pemberdayaan masyarakat Desa yang dikelola secara terpadu, (f) Dukungan pengelolaan kegiatan pelayanan sosial daszar di bidang pendidikan, kesehatan, pemberdayaan warga miskin, pemberdayaan perempuan dan anak, serta pemberdayaan masyarakat marginal dan anggota masyarakat Desa penyandang disabilitas, (g) Dukungan pengelolaan kegiatan pelestarian lingkungan hidup, (h) Dukungan kesiapsiagaan menghadapi bencana alam dan konflik sosial serta penanganannya, (9) dukungan permodalan dan pengelolaan usaha ekonomi produktif yang dikelola oleh BUMDesa dan/atau BUMDesa Bersama, (10) Dukungan pengelolaan usaha ekonomi oleh kelompok masyarakat, koperasi dan/atau lembaga ekonomi masyarakat Desa lainnya, (11) pendayagunaan sumberdaya alam untuk kemandirian Desa dan peningkatan kesejahteran masyarakat, (12) Penerapan teknologi tepat guna untuk pendayagunaan sumberdaya alam dan peningkatan usaha ekonomi pertanian berskala produktif, (13) pengembangan kerja sama antar Desa dan kerja sama Desa dengan pihak ketiga, dan (14) Kegiatan pemberdayaan masyarakat Desa lainnya yang sesuai dengan kewenangan Desa dan diputuskan melalui musyawarah Desa (Permendesa PDTT, 2019).

Pada kenyataannya pemberdayaan tidak cukup sekedar program yang bersifat proyek, pemberdayaan perlu dibuat dalam sebuah proses yang panjang, terutama untuk meningkatkan partisipasi. Pemberdayaan harus sampai pada pembentukan masyarakat madani yaitu yaitu masyarakat yang demokratis, menjunjung tinggi etika dan moralitas, transparan, toleransi, berpotensi, aspiratif, bermotivasi, berpartisipasi, konsisten memiliki bandingan, mampu berkoordinasi, sederhana, sinkron, integral, mengakui, emansipasi, dan ak asasi, namun yang paling dominan adalah masyarakat yang demokratis (Tilaar, 2002).

Masyarakat yang berdaya tidak saja dapat dilihat dari satu sudut pandang ekonomi tetapi mempunyai karakteristik yang kompleks. Menurut Azizy (2004), lima ciri masyarakat madani (berdaya), antara lain, ialah sebagai berikut: (a) terintegrasinya individu dan kelompok eksklusif ke dalam masyarakat melalui kontrak sosial dan aliansi sosial, (b) tersebarnya kekuasaan, sehingga kepentingan yang mendominasi dalam masyarakat dapat dikurangi oleh kekuatan alternatif, (c) terjembataninya kepentingan individu dan negara, karena keanggotaan organisasi volunter mampu memberikan masukan $\mathrm{n}$ terhadap keputusan pemerintah, (d) 
tersebarnya kesetiaan (loyalty) dan kepercayaan (trust), sehingga individu mengakui keterkaitannya dengan orang lain dan tidak mementingkan diri sendiri, dan (e) terbebasnya masyarakat melalui kegiatan berbagai lembaga sosial dengan berbagai perspektif.

Tampak dengan jelas bahwa output dari sebuah pemberdayaan ialah terciptanya sebuah masyarakat yang aktif dan mempunyai tanggung jawab. Dalam perspektif lain, pemberdayaan ialah membangun partisipasi masyarakat. Partisipasi masyarakat sering kali dianggap sebagai bagian yang tidak terlepas dari upaya pemberdayaan masyarakat. Dengan melihat partisipasi sebagai kesatuan dalam proses pemberdayaan masyarakat, akan dapat diketahui bahwa akar perkembangan pimikiran tentang partisipasi dalam pembangunan akan terkait dengan diskursus komunitas. Satu dari berbagai diskursus komunitas ialah asumsi bahwa masyarakat bukan sekumpulan orang bodoh, yang hanya bisa maju kalau mendapatkan perintah belaka. Partisipasi masyarakat ialah keikutsertaan masyarakat dalam proses pengidentifikasian masalah dan potensi yang ada dimasyarakat, pemilihan dan pengambilan keputusan tentang alternatif solusi untuk menangani masalah, pelaksanaan upaya mengatasi masalah, keterlibatan masyarakat dalam proses mengevaluasi perubahan yang terjadi (Adi, 2012).

\section{Perumusan Hipotesis}

Dari kerangka teori yang dikemukakan sebelumnya dapat dirumuskan hipotesis bahwa pemberdayaan masyarakat dan desa dapat menjadi solusi efektif bagi masalah sampah di Indonesia.

\section{METODE PENELITIAN}

Tipe penelitian ini ialah telaah litelatur, dengan pendekatan metode kualitatif. Secara konseptual metode kualitatif ditujukan untuk mendeskripsikan dan menganalisis fenomena, peristiwa, aktivitas sosial, sikap, kepercayaan, persepsi, pemikiran orang, baik secara individual maupun kelompok. Penelitian kualitatif bersifat induktif, peneliti membiarkan berbagai permasalahan muncul dari data atau dibiarkan terbuka untuk interpretasi (Moleong, 2012). Data dihimpun dengan pengamatan yang seksama, mencakup deskripsi dalam konteks yang mendetail, disertai catatan hasil wawancara yang mendalam, dan hasil analisis dokumen.

Penelitian kualitatif ialah penelititan yang bermaksud untuk memahami fenomena tentang apa yang dialami oleh subyek penelitian, seperti perilaku, persepsi, motivasi, dan tindakan,baik dalam konteks pengelolaan sampah orang rumah tangga dan desa juga maupun dalam konteks tatakelola sampah. Metode ini dapat menggambarkan dan mengungkap masalah sampah, dan sekaligus, menggambarkan dan menjelaskan solusi regulasi dan tatalaksana sampah.

Metode pengumpulan data dalam studi ini dilakukan dengan dua teknik, yakni kajian pustaka dan wawancara. Teknik kajian pustaka diterapkan untuk mengkaji dokumen dan arsip mengenai hal yang berkaitan dengan penelitian. Penggunaan kajian pustaka terutama dipakai untuk dua hal berikut: (a) kajian kebijakan tentang sampah, tentang lingkungan, dan permukiman dan tentang desa dari mulai undangundang, peraturan pemerintah, peraturan menteri, peraturan dearah sampai dengan peraturan desa, dan (b) kajian teori pemberdayaan dan yang relevan dengan kegiatan riset. teknik wawancara dilakukan kepada berbagai pihak berikut: (a) 
pegawai dinas pemberdayaan dan desa, dinas lingkungan hidup kebersihan dan pertamanan, serta ekpert pembuatan produk hukum daerah di DPRD Kabupaten Garut, (b) dua orang kepala desa di kecamatan tarogong kidul kabupaten garut yang telah melakukan pengelolaan sampah rumah tangga secara aktif, dan (c) LSM lingkungan hidup dan praktisi pemberdayaan masyarakat serta pendamping desa di Kabupaten Garut. Berbagai pertanyaan yang diberikan kepada informan bersifat open ended dan mengarah kepada kedalaman informasi dengan dilengkapi teknik kecakapan.

Teknik analisis data dalam studi ini ialah dengan cara mengidentifikasi substansi masalah, mencari makna dan akar masalah dari setiap data dan fenomena yang ditemukan, baik dari referensi maupun dari hasil wawancara. Analisis data juga menentukan relevansi dan urgensi dari setiap data terhadap solusi tata kelola sampah di Indonesia.

\section{HASIL DAN PEMBAHASAN}

\section{Hasil}

Hasil kajian literatur dan diskusi dengan para pelaku, meliputi empat temuan penting yang relevan dengan tujuan penelitian. Diperoleh dua hasil yang berkaitan dengan tujuan penelitian "Merumuskan pola dan tahapan pemberdayaan masyarakat yang efektif dalam tata kelola sampah rumah tangga".

Pertama, pemberdayaan dimulai dari pembangkitkan etik, moral, kesadaran, mindset, dan tanggung jawab terhadap lingkungan di masyarakat. Pemberdayaan pada dasarnya ialah membangkitkan potensi di dalam diri warga untuk membangun visi lingkungan desanya, mengubah pemikiran tentang sampah, dan bertanggung jawab terhadap lingkungan yang ada di desanya. Pemberdayaan ialah membantu warga untuk menyadari perannya dalam menjaga lingkungan. Memaknai bahwa pengelolaan sampah ialah tugas hidup, sehingga muncul kesadaran dan kesanggupan untuk menjadi solusi sampah dengan dimulai dari rumah masingmasing. Model pemberdayaan yang relevan melalui Focus Group Discussion (FGD) sampah di lingkungan masing-masing, dan dengan proses pembelajaran orang dewasa (androgogy).

Kedua, pemberdayaan masyarakat dalam tata kelola sampah rumah tangga efektif dilakukan mulai dari tingkat RT/RW. Pola pemberdayaan masyarakat dalam tata kelola sampah perlu dimulai dari organisasi tingkat RT/RW agar partisipasi warga meningkat. Hal ini diperlukan karena skala yang terlalu besar menghambat partisipasi dari orang potensial. Teknis pemberdayaan memerlukan penggerak partisipasi, dalam hal ini tokoh formal (RT/RW), tokoh informal, dan relawan di tingkat RT/RW untuk mengumpulkan sampah-sampah dari masing-masing rumah. Selain itu, sangat penting untuk memperhatikan tahapan pemberdayaan secara benar. Pemberdayaan dimulai dari menilai sumber daya di RT/RW, mendiskusikan masalah dengan representasi warga, serta merumuskan masalah secara bersamasama.

Diperoleh dua hasil yang berhubungan dengn tujuan penelitian "Merumuskan model pemberdayaan desa agar mempunyai kapasitas dalam tatakelola sampah rumah tangga di Indonesia" ialah sebagai berikut. Pertama, penguatan Desa diperlukan dengan cara mendelegasikan kewajiban tata kelola sampah dari 
Kabupaten/Kota kepada Desa. Desa perlu menjadi fokus utama penyelesaian masalah sampah di Indonesia, untuk membantu pemerintah kabupaten/kota yang terbukti kurang efektif dalam penanganan masalah desa. Peran desa perlu dikuatkan oleh berbagai aturan yang relevan. Kedua, perlu desain tatakelola sampah yang inovatif dan komprehensif sesuai dengan regulasi desa yang relevan. Hanya sedikit desa yang sudah memahami berbagai aturan yang terkait dengan sampah. Pada sisi lain, hasil penelitian memperlihatkan bahwa aturan untuk mendukung tata kelola sampah di desa sudah sangat lengkap, baik dari kemendagri maupun kememendesa. Kemendesa lebih mengatur aspek pemberdayaan dan pembangunan di desa, sementara kemendagri menangani aspek pembinaan dan penyelenggaraan pemerintahan desa. Dalam konteks tata kelola sampah, beberapa peraturan kemendesa yang relevan diperlihatkan pada Tabel 1 .

Tabel 1. Hasil Analisis Mengenai Peraturan Kemendesa yang Relevan

\begin{tabular}{|c|c|c|}
\hline No. & Permendesa & Kaitan dengan Tatakelola Sampah \\
\hline 1. & $\begin{array}{l}\text { Permendesa Nomor } \\
02 \text { Tahun } 2015 \\
\text { tentang Tata Tertib } \\
\text { Musyawarah Desa }\end{array}$ & $\begin{array}{l}\text { Kebutuhan sarana prasarana dan lokasi } \\
\text { tatakelola sampah sampah harus diusulkan dalam } \\
\text { musyawarah desa sehingga dapat dimasukan ke } \\
\text { dalam RPJMDes, RKPdes dan dianggarkan } \\
\text { dalam ABPDes }\end{array}$ \\
\hline 2. & $\begin{array}{l}\text { Permendesa Nomor } \\
03 \text { Tahun } 2015 \\
\text { tentang } \\
\text { Pendampingan Desa }\end{array}$ & $\begin{array}{l}\text { Jika diperlukan desa menganggarkan biaya } \\
\text { pendampingan untuk proses daur ulang sampah } \\
\text { dan mengerakan partisipasi, agar tata kelola } \\
\text { sampah mendapat bantuan teknis/pendampingan } \\
\text { dari para professional }\end{array}$ \\
\hline & $\begin{array}{l}\text { Permendesa Nomor } \\
04 \text { Tahun } 2015 \\
\text { tentang BUMDes }\end{array}$ & $\begin{array}{l}\text { Desa dapat mengalokasi anggaran untuk modal } \\
\text { usaha pengelolaan sampah, dengan cara } \\
\text { membentuk BUMDES, salah satu unit usaha } \\
\text { bumdes yang potensial adalah bank sampah }\end{array}$ \\
\hline & $\begin{array}{l}\text { Permendesa Nomor } \\
02 \text { Tahun } 2016 \\
\text { tentang Indeks Desa } \\
\text { Membangun }\end{array}$ & $\begin{array}{l}\text { Ketahanan lingkungan masuk ke dalam Indeks } \\
\text { Desa Membangun merupakan indeks komposit } \\
\text { yang terdiri dari: (a) Indeks Ketahanan Sosial } \\
\text { (IKS); (b) Indeks Ketahanan Ekonomi (IKE); dan } \\
\text { (c) Indeks Ketahanan Lingkungan (IKL). Hanya } \\
\text { saja dalam pengelolaan sampah mendapat porsi } \\
\text { penilaian yang sedikit, perlu ditingkatkan dalam } \\
\text { bentuk perda, dan perdes. }\end{array}$ \\
\hline & $\begin{array}{l}\text { Permendesa Nomor } \\
09 \text { Tahun } 2016 \\
\text { tentang Pelatihan } \\
\text { Masyarakat }\end{array}$ & $\begin{array}{l}\text { Menjadi dasar untuk desa menganggarkan } \\
\text { kegiatan pelatihan pengelolaan sampah yang } \\
\text { dibiayai oleh APBDes. }\end{array}$ \\
\hline & $\begin{array}{l}\text { Permendesa No. } 16 \\
\text { Tahun } 2018 \text { tentang } \\
\text { prioritas penggunaan } \\
\text { anggaran dana desa } \\
\text { tahun } 2019\end{array}$ & $\begin{array}{l}\text { Setiap tahun terbit permendesa tentang prioritas } \\
\text { penggunaan dana desa, dalam hal ini kementerian } \\
\text { desa dapat mendorong secara spesifik terhadap } \\
\text { alokasi anggaran untuk infrastruktur kesehatan } \\
\text { lingkungan baik, sampah, rumah tidak layak } \\
\text { huni, MCK dan pengendalian penyakit. }\end{array}$ \\
\hline
\end{tabular}


Sementara itu, kemendagri yang membawahi bidang penyelenggaraan pemerintah desa dan pembinaan masyarakat, dua peraturan yang relevan dengan tata kelola sampah di desa dikemukakan pada Tabel 2.

Tabel 2 Hasil Analisis Mengenai Permendagri yang Relevan

\begin{tabular}{|c|c|c|}
\hline No. & Permendagri & Kaitan dengan Tatakelola Sampah \\
\hline 1. & $\begin{array}{l}\text { Permendagri Nomor } \\
111 \text { Tahun } 2014 \\
\text { tentang Pedoman } \\
\text { Teknis Peraturan Di } \\
\text { Desa. }\end{array}$ & $\begin{array}{l}\text { Menjadi rujukan dalam pembuatan peraturan desa } \\
\text { dalam pengelolaan sampah skala desa. Dapat } \\
\text { dibuat peraturan desa bebas residu sampah yang } \\
\text { menjadi dasar perumusan Rencana Pembangunan } \\
\text { Jangka Menengah Desa (RPJMDes), Rencana } \\
\text { Kerja Pemerintahan Desa (RKPDes) dan APBDes } \\
\text { yang secara tegas mengalokasikan angaran untuk } \\
\text { tatakelola sampah di desa. }\end{array}$ \\
\hline 2. & $\begin{array}{l}\text { Permendagri Nomor } \\
20 \text { Tahun } 2018 \\
\text { tentang Pengelolaan } \\
\text { Keuangan Desa }\end{array}$ & $\begin{array}{l}\text { Terdapat kode rekening khusus yang bisa diisi } \\
\text { dengan anggaran sampah, baik yang bersifat } \\
\text { belanja modal, mapun belanja barang dan jasa, } \\
\text { sehingga pengalokasian tersebut sangat dibenarkan } \\
\text { oleh aturan. Permendagri No } 20 \text { Tahun } 2018 \\
\text { Menjadi rujukan desa. Dalam hal ini sarana dan } \\
\text { prasarana dimasukan ke dalam pos anggaran } \\
\text { bidang pembangunan desa, sedangkan } \\
\text { pembangunan teknologi informasi, pelatihan warga } \\
\text { dalam tatakelola sampah dimasukan ke dalam pos } \\
\text { bidang pemberdayaan masyarakat. }\end{array}$ \\
\hline
\end{tabular}

Sumber: Hasil Analisis.

Dari telaah terhadap dokumen desa diketahui bahwa pemberdayaan desa satu dengan lainnya di seluruh Indonesia mirip, bahkan kode rekening, jenis kegiatan, dan mekanisme penganggaran ialah serupa. Dengan demikian, model penguatan desa dapat diimplementasi secara relatif di seluruh Indonesia.

\section{Pembahasan}

Hasil penelitian menunjukkan, bahwa pemberdayaan dimulai dari pembangkitan etika, moral, kesadaran, pikiran, dan tanggung jawab terhadap lingkungan di masyarakat. Temuan ini memperlihatkan, bahwa hal paling mendasar dari pemberdayaan ialah membangkitkan potensi yang ada di dalam diri bukan dengan memberikan stimulasi bantuan uang, sarana, dan prasarana. Pendekatan proyek tidak akan berhasil, sebelum potensi internal dan modal sosial masyarakat yang telah ada sebelumnya dibangkitkan. Keperluan ini, membutuhkan upaya secara bersungguhsungguh untuk membangun keberdayaan dari substansi paling dasar. Selain itu, diperlukan juga optimisme bahwa pemberdayaan efektif dan harus jadi titikmemulai (entry point) pembentukan masyarakat madani. Masyarakat berdaya ialah masyarakat yang proaktif dan mampu menata dirinya dengan baik. Masyarakat yang sudah tidak lagi bergantung pada inisiatif dan pengarahan dari pemerintah. Masyarakat madani mempunyai peradaban sangat tinggi. Sudah saatnya, tata kelola sampah menjadi satu dari berbagai media media (instrumen) untuk mendidik masyarakat lebih disiplin, lebih peduli pada soal lingkungan, mengenal teknologi pengelolaan sampah yang lebih ramah 
lingkungan, dan membentuk sebuah masyarakat yang lebih tertib hukum. Masyarakat madani ialah sebuah keniscayaan, hanya saja untuk membentuk itu diperlukan sebuah pendekatan yang tepat.

Memilih tata kelola sampah sebagai titik-memulai pembangunn masayarakat madani didasarkan pada tiga pertimbangan berikut: (a) partisipasi ialah kata kunci masyarakat madani, (b) di dalam partisipasi ada nilai kebersamaan dan kolaborasi, dan (c) di dalam partisipasi ada kesadaran tinggi akan ketaatan hukum. Ketiga hal ini dapat dibangun melalui upaya tata kelola sampah secara komprehensif dan berkelanjutan. Solusi sampah memerlukan partisipasi, memerlukan nilai baik di masyarakat, tanggung jawab, dan penuh kepedulian. Pengelolaan sampah juga mengharuskan warga untuk taat terhadap peraturan, baik peraturan tertulis maupun tidak tertulis. Pengelolaan sampah juga menuntut visi bersama untuk membangun kawasan yang lebih sehat, lebih bersih, lebih tertata, dan lebih harmoni dengan lingkungan sekitar.

Hasil penelitian yang menunjukkan bahwa pemberdayaan masyarakat dalam tata kelola sampah rumah tangga efektif dilakukan mulai dari tingkat RT/RW, mengandung arti akan perlunya tata kelola sampah organisasi sekecil mungkin untuk meningkatkan jumlah partisipan. Semakin banyak partispan yang terlibat semakin banyak jumlah orang yang dapat berpartisipasi dan berkepentingan dalam penanganan sampah sangat besar, bisa mencapai puluhan juta orang. Mereka yang dapat dilibatkan ialah jutaan anak sekolah, jutaan rumah tangga, dan 74.957 desa, dapat secara serentak membuat sebuah gerakan sosial besar. Isu sampah bisa mempersatukan komunitas yang tercerai berai akibat konflik politik di Indonesia, karena fanatisme kelompok mendukung calon presiden dan partai politik tertentu.

Agenda pengelolaan sampah secara nasional, melalui sebuah gerakan struktural dan kultural, diharapkan dapat menjadi satu di antara berbagai cara menemukan persatuan antar warga secara lebih indah. Penanganan lingkungan hidup, terutama sampah, dapat dilakukan secara lintas batas ideologi, preferensi politik, dan kesukuan. Kebersihan, kesehatan, dan lingkungan hidup merupakan kebutuhan universal. Jika pada politik mungkin sesama anak bangsa bertikai, tetapi dalam tata kelola sampah sudah selayaknya bergandengan tangan, berkolaborasi menjalankan berbagai program pro lingkungan.

Hasil penelitian menunjukan bahwa penguatan desa diperlukan dengan cara mendelegasikan kewajiban tata kelola sampah dari Kabupaten/Kota kepada Desa, bermakna bahwa peran desa harus diperkuat, diperjelas, dan diperbesar agar betulbetul efektif. Dalam menjalankan peran tersebut, diperlukan enam langkah kongkrit sebagai berikut.

Pertama, Pemda membuat perda pengelolaan sampah. Umumnya seluruh kabupaten/kota di Indonesia sudah mempunyai, karena pedoman pembuatannya sudah dikeluarkan pemerintah pusat bahkan berikut dengan contoh naskah akademik dan draft perdanya secara komprehensif. Pada beberapa kabupaten, sperti di Kabupaten Garut bahkan sudah dilengkapi dengan perda Kebersihan. Perda ini sebagai dasar untuk mengeluarkan kebijakan delegasi dalam bentuk peraturan bupati tentang Desa Bebas Residu Sampah (Desa Bersih).

Kedua, Bupati/walikota membuat Peraturan Bupati/Walikota mengenai desa bebas residu sampah. Dengan Peraturan Bupati/Walikota ini, diatur tata laksana pengelolaan sampah permukiman di desa secara lengkap, termasuk menggunakan sumber anggaran dari APBDes. Prasarana dan sarana standar yang wajib diadakan 
oleh desa. Selain itu, Peraturan Bupati/Walikota tentang desa bersih dapat diperkuat melalui Peraturan Bupati/Walikota tentang APBDes yang dikeluarkan setiap awal tahun sebagai pedoman bagi Desa menyusun APBDes tahunan.

Ketiga, desa membuat Peraturan Desa tentang Desa Bebas Residu Sampah. Peraturan Desa mengatur secara rinci hak dan kewajiban desa, kelembagaan, alokasi anggaran, dan partisipasi masyarakat. Peraturan Desa dilengkapi oleh RPJMDes, RKPDes, dan APBDes.

Keempat, Desa meningkatkan partisipasi masyarakat dengan model pemberdayaan mulai dari level RT/RW. Tentu saja kegiatan ini didorong oleh bantuan dana untuk pembangunan TPS, dan TPSA per RT dan RW. Selain itu, perlu disertai oleh pendampingan dan pelatihan yang besumber dari APBDes.

Kelima, Desa mewujudkan efektivitas tata kelola sampah melalui pembentukan unit usaha bank sampah pada BUMDES, dan berbagai pelatihan tambahan untuk meningkatkan nilai ekonomi sampah.

Keenam, Pemerintah Kabupaten/Kota dapat melakukan monev dengan mengoptimasi peran Camat agar aktif turun ke desa. Pemerintah juga dapat mendeain sebuah aplikasi pemantauan lingkungan secara mobile yang mudah diakses untuk meningkatan pengendalian. Dengan monev dan pengendalian yang intensif maka pemerintah dapat menerapkan konsep insentif dan disinsentif bagi desa dan kecamatan yang berprestasi dan yang buruk tata kelola sampahnya.

Dengan demikian, solusi sampah bukan di TPA tetapi di hulunya, yaitu pada setiap rumah tangga yang dikelola per RT dan RW. Jika konsep ini diterapkan di seluruh Indonesia, visi Indonesia Bebas Sampah akan dapat dicapai dalam dua tahun saja. Tentu saja hal ini sangat optimis, karena melibatkan seluruh desa di Indonesia, jutaan partisipasi warga dan konsolidasi dana lingkungan bisa mencapai Rp 7,4 Triliun dengan asumsi setiap desa dapat mengalokasikan dana untuk tata kelola sampah senilai Rp 100 Juta per tahun.

Hasil penelitian yang menunjukkan bahwa regulasi desa sudah sangat komprehensif mengandung makna, bahwa secara konsepsiaonal dan regulasi sudah sangat siap, tinggal didorong oleh regulasi pemda agar desa mempunyai tanggung jawab dalam mengelola sampah dalam skala desa.

\section{KESIMPULAN}

Pemberdayaan masyarakat ialah solusi paling efektif dalam tata kelola sampah rumah tangga, karena dengan masyarakat yang berdaya setiap rumah tangga dapat berpartisipasi menyelesaikan masalah sejak dini. Pemberdayaan terkait dengan etik, moral, kesadaran kebudayaan, motivasi dan visi lingkungan. Untuk itu diperlukan pemberdayaan secara; kelembagaan dan teknis tatalaksana sehingga dapat mengerakan masyarakat melalui berbagai kebijakan di tingkat desa. Diperlukan dukungan kebijakan di tingkat kabupaten dalam bentuk perda dan perbup/perwali yang didetail sampai dengan perdes, RPJMDes, RKPDes, APBDes di masingmasing desa yang mengatur tentang tatalaksana sampah dan pengoalokasian dana untuk capacity building tatakelola sampah di desa.

Pengelolaan desa harus menjadi urusan wajib desa, sehingga dengan demikian, seluruh sampah rumah tangga harus selesai diolah di desa. Mewujudkan kabupaten kota di Indonesia bebas sampah. 


\section{REFERENSI}

Adi, I. R. (2012). Pemberdayaan Masyarakat dan Partisipasi Masyarakat. Edisi Revisi. Jakarta: Raja Grafindo Persada.

Azizy, A. Q. A. (2004). Melawan Globalisasi: Reinterpretasi Ajaran Islam: Persiapan SDM dan Terciptanya Masyarakat Madani. Yogyakarta: Pustaka Pelajar.

Badan Pusat Statistik. (2010). Sensus Penduduk 2010. Jakarta: Badan Pusat Statistik.

Barrow, C. (2006). Environmental management for sustainable development. UK: Routledge.

Isbandi R.A. (2012). Pemberdayaan Masyarakat dan Partisipasi Masyarakat. Edisi Revisi. Jakarta: Raja Grafindo Persada.

Moleong, L. J. (2012). Metodologi Penelitian Kualitatif. Bandung: PT Remaja Rosda Karya.

Peraturan Daerah Kabupaten Garut. (2014). Pengelolaan Sampah Rumah Tangga Dan Sampah Sejenis Sampah Rumah Tangga. Garut: Kemendagri.

Peraturan Desa Segobang. (2017). Pengelolaan Sampah. Segobang: Badan Permusyawaratan dan Kepala Desa Segobang.

Peraturan Pemerintah Republik Indonesia. (2012). Pengelolaan Sampah Rumah Tangga dan Sampah Sejenis Sampah Rumah Tangga. Jakarta: Kemensesneg.

Permen Lingkungan Hidup. (2011). Pedoman Materi Muatan Rancangan Peraturan Daerah tentang Pengelolaan Sampah Rumah Tangga Dan Sampah Sejenis Sampah Rumah Tangga. Jakarta: Kementerian Lingkungan Hidup dan Kehutanan Republik Indonesia.

Permen Lingkungan Hidup. (2012). Pedoman Pelaksanaan Reduce, Reuse, Recycle melalui Bank Sampah. Jakarta: Kementerian Lingkungan Hidup dan Kehutanan Republik Indonesia.

Permendagri. (2010). Pedoman Pedoman Pengelolaan Sumber Daya di Wilayah Laut. Jakarta: Kemendagri.

Permendagri. (2014). Pedoman Teknis Peraturan di Desa. Jakarta: Kemendagri. Permendagri. (2018). Pengelolaan Keuangan Desa. Jakarta: Kemendagri.

Permendesa PDTT (2015). Tata Tertib Musyawarah Desa. Jakarta: Kemendesa PDTT.

Permendesa PDTT. (2015a). BUMDes. Jakarta: Kemendesa PDTT.

Permendesa PDTT. (2015b). Pendampingan Desa. Jakarta: Kemendesa PDTT.

Permendesa PDTT. (2016). Indeks Desa Membangun. Jakarta: Kemendesa PDTT.

Permendesa PDTT. (2016a). Pelatihan Masyarakat. Jakarta: Kemendesa PDTT.

Permendesa PDTT (2019). Prioritas Penggunaan Dana Desa Tahun 2019. Jakarta: Kemendesa PDTT.

Phelps, J., Dermawan, A., \& Garmendia, E. (2017). Institutionalizing environmental valuation into policy: Lessons from 7 Indonesian agencies. Global environmental change, 43, 15-25.

Putrawan, I. M. (2014). Konsep-konsep Dasar Ekologi dalam Berbagai Aktivitas Lingkungan. Bandung: Alfabeta.

Tilaar, H.A.R. (2002). Pendidikan, Kebudayaan, dan Masyarakat Madani Indonesia. Bandung: PT Remaja Rosdakarya. 
Undang-Undang Republik Indonesia. (1992). Perumahan dan Permukiman. Jakarta: Kemenkumham.

Undang-Undang Republik Indonesia. (2004). Pemerintahan. Jakarta: Kemenkumham.

Undang-Undang Republik Indonesia. (2008). Pengelolaan Sampah. Jakarta: Kemenkumham.

Undang-Undang Republik Indonesia. (2009). Perlindungan dan Pengelolaan Lingkungan Hidup. Jakarta: Kemenkumham.

Veitch, R., \& Arkkelin, D. (1995). Environmental psychology: An interdisciplinary perspective. New Jersey: Prentice-Hall Inc. 